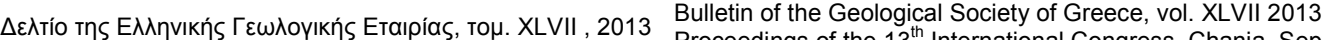

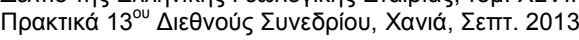
2013

\title{
THRUST TECTONICS IN THE CENTRAL PART OF THE EXTERNAL HELLENIDES, THE CASE OF THE GAVROVO THRUST
}

\author{
Kamberis E. ${ }^{1}$, Sotiropoulos S. ${ }^{1}$, Marnelis F. ${ }^{1}$ and Rigakis N. ${ }^{1}$ \\ ${ }^{1}$ Hellenic Petroleum S.A. Exploration and Production of Hydrocarbons, $8^{A}$, Chimaras Str., 15125, \\ Maroussi,Athens,ekamperis@hotmail.gr,ssotiropoulos@helpe.gr,fedmarn@yahoo.gr,nrigakis \\ @helpe.gr
}

\begin{abstract}
Thrust faulting plays an important role in the structural deformation of Gavrovo and Ionian zones in the central part of the 'External Hellenides' fold-and-thrust belt. The Skolis mountain in NW Peloponnese as well as the Varassova and Klokova mountains in Etoloakarnania are representative cases of ramp anticlines associated with the Gavrovo thrust.

Surface geology, stratigraphic data and interpretation of seismic profiles indicate that it is a crustal-scale thrust acted throughout the Oligocene time. It is characterized by a ramp-flat geometry and significant displacement (greater than 10 $\mathrm{km})$. Out of sequence thrust segmentation is inferred in south Etoloakarnania area. Down flexure and extensional faulting in the Ionian zone facilitated the thrust propagation to the west. The thrust emplacement triggered halokenetic movement of the Triassic evaporites in the Ionian zone as well as diapirisms that were developed in a later stage in the vicinity of the Skolis mountain.

Key words: thrusting, thrust propagation, normal faulting.
\end{abstract}

\section{Пєрі́ $\eta \psi \eta$}

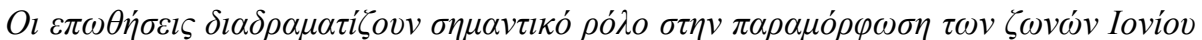

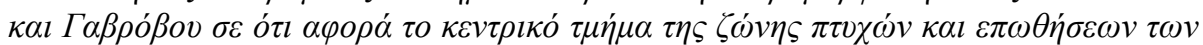

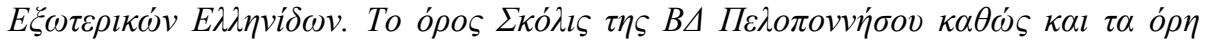

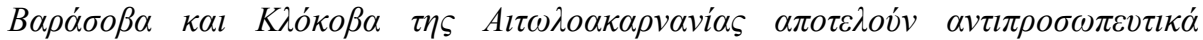

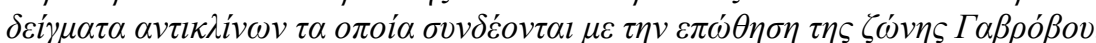

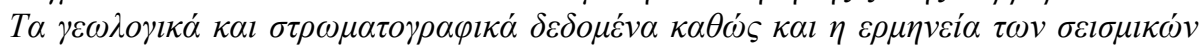

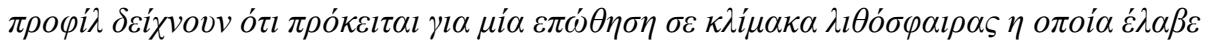

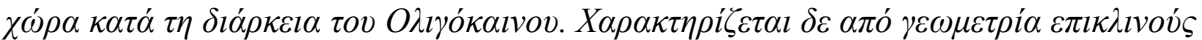

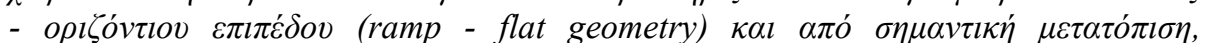

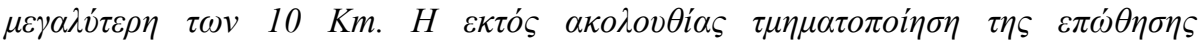

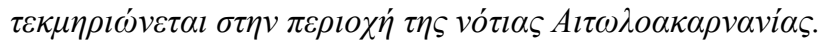

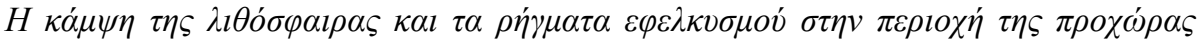

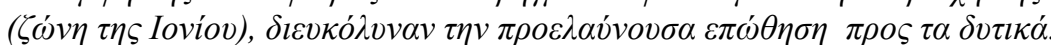

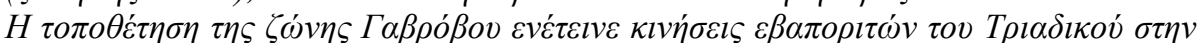

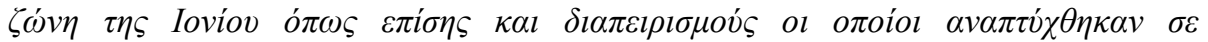

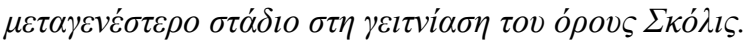

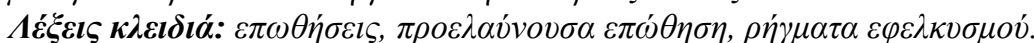

XLVII. No $2-540$ 


\section{Introduction}

Structural and stratigraphic studies carried out in the External Hellenides in the last three decades support a model of foreland propagating thrust faults (Fleury, 1980; Brooks et al., 1988). The previous Mesozoic 'isopic' zones (Aubouin, 1959) were inverted during Tertiary, forming major thrust sheets carrying rocks from east to west onto the relatively autochton Pre-Apulian zone.

This paper focuses to Gavrovo thrust (GT) that is exposed in the central part of External Hellenides, in particular in NW Peloponnese and SW Etoloakarnania regions (Figure 1a). Surface structural and biostratigraphic data as well as subsurface data based on interpretation of seismic profiles reveal information about the geometry and the evolution of GT.

\section{Tectonic Setting}

In early Mesozoic times, Western Greece was part of the Apulian passive continental margin. A Triassic - early Jurassic rifting stage differentiated the Apulian margin, resulting into the formation of a series of deep basins and platforms. The collision between the Apulian and Eurasia plates in late Cretaceous and the final closure of the Neo-Tethys had as a consequence the intra-continental deformation propagating towards Apulian throughout Tertiary (Dewey et al., 1973). The end result was the 'External Hellenides' fold-and-thrust belt (FTB) representing a pile of NW-SE striking nappes separated by major foreland propagated thrust faults that become progressively younger westwards (Figure 1a). During this orogenic process, initially the Pindos zone was detached from its basement in the Late Eocene and it thrust over the flysch of the Gavrovo zone. During Oligocene, the Gavrovo zone was also involved in the ongoing deformation in the study area and it thrust over the flysch of the Ionian zone at the end of this time period.

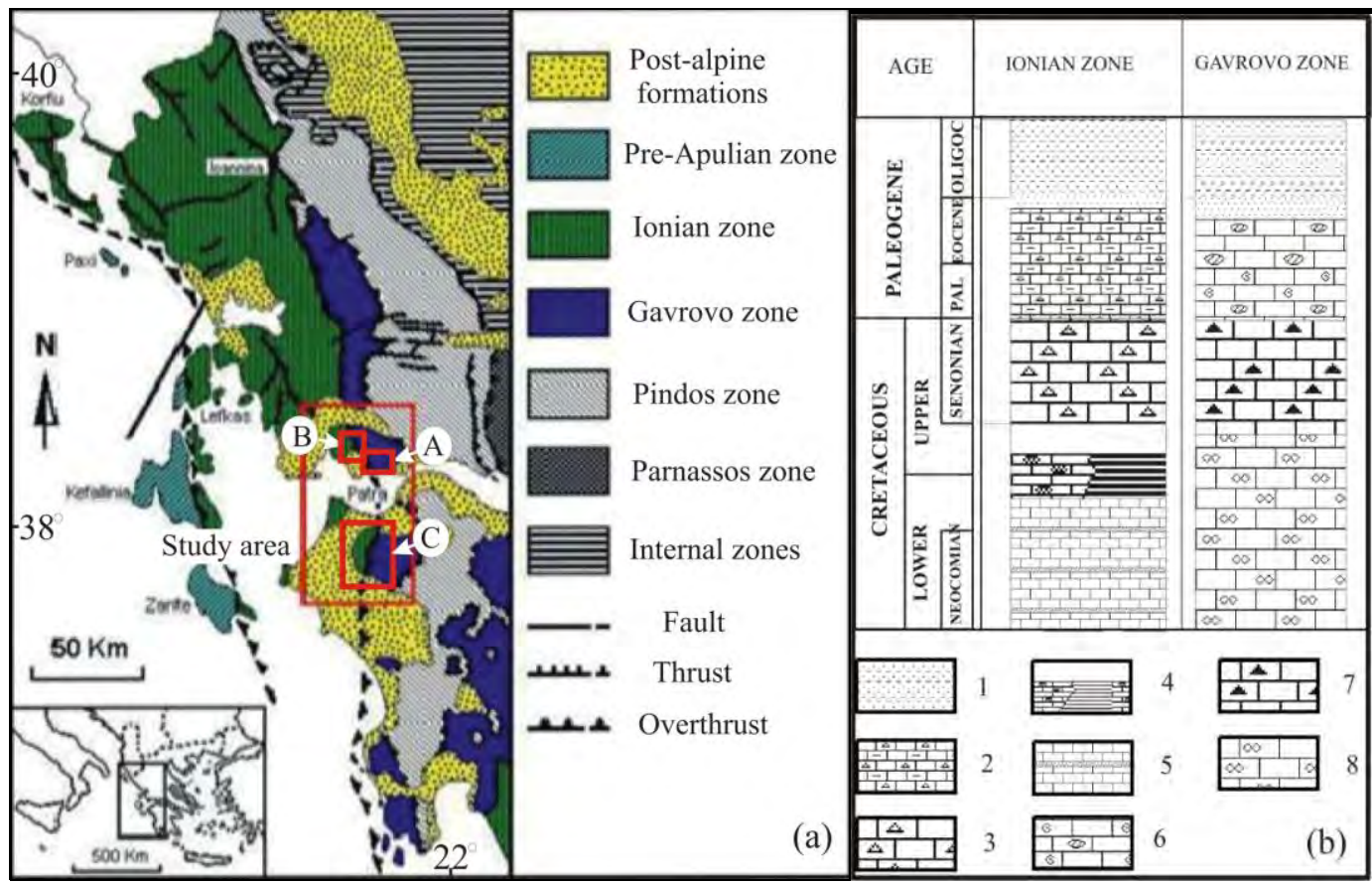

Figure 1 - (a): Location map of the study area in the central part of External Hellenides. A, $B$ and $C$ are locations of geological maps that will be presented in Figures 2, 4 and 5. (b): Stratigraphic columns of the Ionian and Gavrovo zones in Western Greece (1: flysch, 2: limestones-cherts with clastics, 3: pelagic limestones with clastics, 4 : pelagic limestonescherts-shales, 5: pelagic limestones-cherts, 6: platform carbonates with clastics, 7: reefalbioclastic carbonates, 8: platform carbonates (Rigakis, 1999, partly modified). 
The Ionian thrust emplacement on the pre-Apulian zone, which is considered as the slope of the Apulian platform, took place in the early Pliocene. Active compression is affecting the more external part of the FTB since Pliocene, whereas at the same time extension predominates backwards (Underhill, 1989; Doutsos \& Kokkalas, 2001). Nowadays, Kefallinia transform fault delineates the structural boundary of two regions; the northern one, where collision occurs between Apulian plate and Eurasian continent, and the southern one, where an active subduction of the Ionian oceanic crust takes place beneath the Hellenic FTB (Underhill, 1989).

\section{Geological Setting and Field Data}

The study area is located in the south Etoloakarnania and northwest Peloponnese and it belongs to the Ionian and Gavrovo zones (Figure 1a). Thick turbiditic fan facies outcrop widely covering the carbonate sequences of above zones (IFP, 1966; BP, 1971; Fleury, 1980; Sotiropoulos et al., 2003; 2008; Kamberis et al., 2005). The upper part of the Gavrovo carbonate sequence comprises Upper Cretaceous to Eocene shallow marine carbonates (Figure 1b). They are exposed in Varassova and Klokova mountains in south Etoloakarnania as well as in Skolis mountain in northwest Peloponnese (Fleury, 1980). Eocene to earliest Oligocene transitional beds overlie conformably the carbonate series on Klokova and Skolis mountains marking the onset of the turbidites deposition in the study area (Fleury, 1980; Kamberis et al., 2000; Sotiropoulos et al., 2003).

The widespread occurrence of turbidites suggests the existence of a foreland basin that has been formed due to the westward propagation of Pindos thrust (Clews, 1989). In addition, its internal differentiation is associated with the Pindos and the GT evolution (Kamberis et al., 2000; 2005; Sotiropoulos et al., 2003). The turbidites deposition ceased in Late Oligocene revealing the age of the emplacement of GT (Kamberis et al., 2000; Sotiropoulos et al., 2003). The foreland basin was characterised by a low subsidence rate in the first stage of its evolution during late Eocene earliest Oligocene, whereas during early Oligocene it was characterised by maximum width and high sedimentation rates. Distal fan facies were deposited in the Ionian part of the foreland basin, while more proximal facies were deposited in the same time in the Gavrovo part of the foreland basin (Sotiropoulos et al., 2003; Kamberis et al., 2005). At the end of the early Oligocene and the beginning of Late Oligocene the facies become more proximal throughout the foreland basin and this fact is associated with the westward propagation of Pindos thrust as well as with the intensive thrust fault activity in the Gavrovo zone (Kamberis et al., 2000; Sotiropoulos et al., 2003; 2008). This fault activity resulted to the successive repetitions and the overall structural thickening of the flysch sequence.

\subsection{SW Etoloakarnania Area}

The boundary between Ionian and Gavrovo zones is structural and it is located on the western flanks of Varassova mountain. Some authors consider that GT represents an inverse fault (Aubouin, 1959; IFP, 1966; BP, 1971), while others support that is a major thrust, accompanied with great displacement (Fleury, 1980, Kamberis et al. 2000, Sotiropoulos et al., 2003). In this position, Cretaceous limestones thrust over flysch sediments of Ionian zone (Figure 2). A westverging narrow asymmetric anticline plunging to the north lies on the hangingwall of the GT. Its short forelimb is characterized by subvertical strata while the backlimb by east to northeast dipping strata (Figure 2). The flysch on the footwall block is intensively deformed by imbricates and tight folding in particular at the northwestern slopes of Varassova mountain (Sotiropoulos et al., 2003, Figure 2).

A second NW trending and eastward dipping thrust fault occurs at the southern part of Varassova mountain. Moreover, NNW-SSE trending normal faults dipping to the east downthrown the carbonates at the eastern flank of Varassova mountain; the latter faults could initially act as thrust faults and then as gravitational faults due to tilting of the hanging wall strata (Figure 2). 


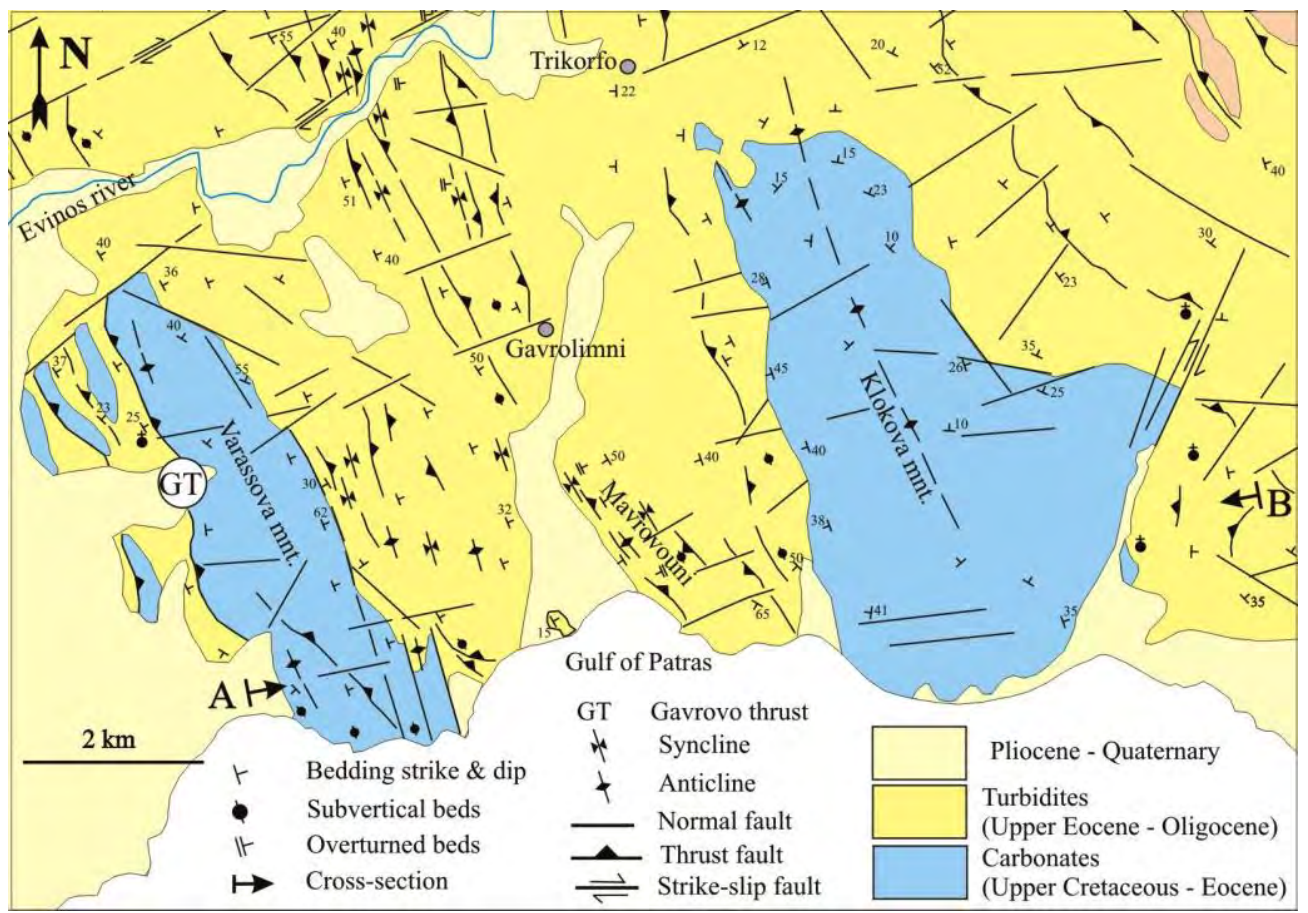

Figure 2 - Geological map of the Klokova - Varassova area. Location A in Figure 1a (Sotiropoulos, 2005).

A narrow elongated area occupied by hills (i.e. Mavrovouni hill), is located between Varassova and Klokova mountains). It represents a pop-up structure bounding to the west and to the east by thrust faults (Figures $2 \& 3$, Sotiropoulos et al., 2003). Heading eastwards, close to the western flank of Klokova mountain, another thrust fault was identified. It is a NNW-SSE trending and east-dipping thrust fault that runs parallel to the axis of Klokova anticline. Its northern prolongation reaches up to the Evinos river (Sotiropoulos 2005, Figure 2).

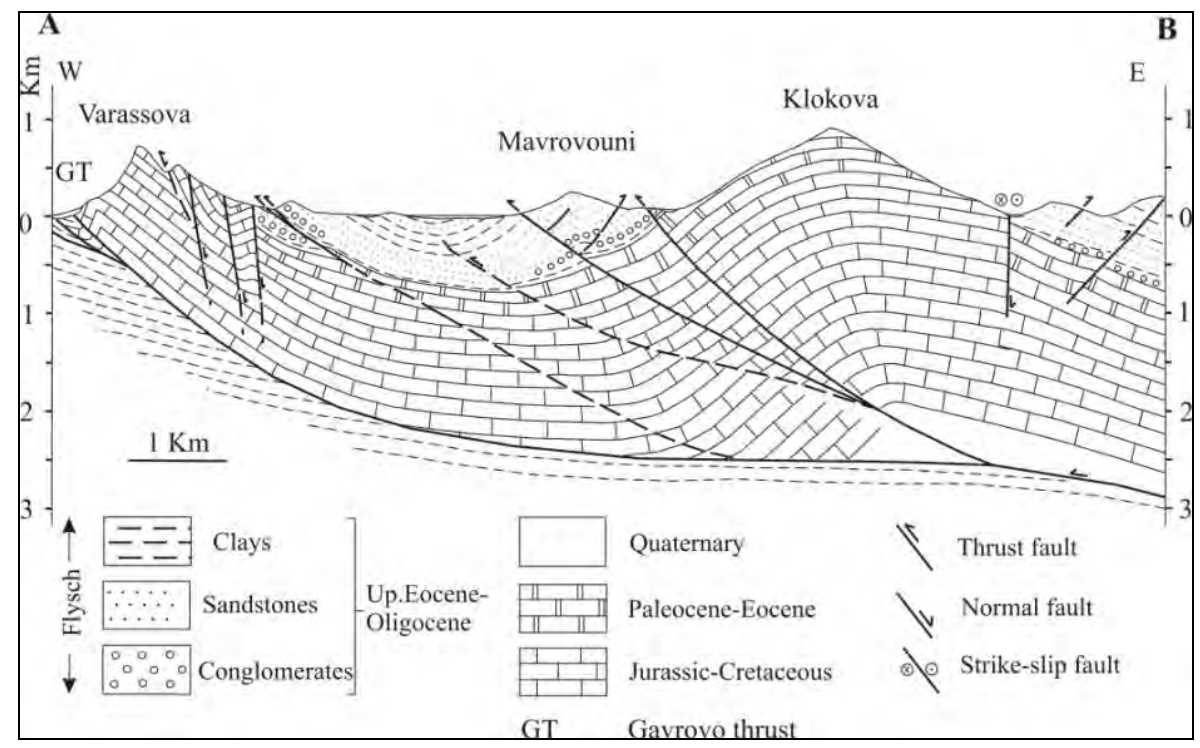

Figure 3 - Geological cross-section. Its position is shown in Figure 2 (Sotiropoulos et al., 2003).

$\underline{\text { XLVII, No } 2-543}$ 
A broad west-verging anticline plunging to the north lies at the Klokova mountain. It is asymmetric in shape with a steep forelimb and a gently dipping to the east backlimb, while its axial part is generally sub-horizontal (BP, 1971). Minor west-dipping backthrusts have been identified southeast of Klokova mountain as well as a NE-SW trending dextral strike-slip fault bring in structural contact carbonates with flysch (Figures $2 \& 3$ ). Taking into consideration the above distribution of dips on Varassova and Klokova anticlines, it is suggested that the above folds represent hangingwall anticlines closely associated with the geometry of GT (Sotiropoulos et al., 2003, Figure 3).

In an effort to track the northern prolongation of the GT, Two major elongated west verging and eastward dipping thrust fault zones have been identified northwest of Varassova mountain (Figure 4). The western fault zone runs for at least $11 \mathrm{~km}$ on the western flank of Arakynthos mountain reaching a width of $1.7 \mathrm{~km}$ at its central part (Sotiropoulos 2005, Figure 4). Most of the thrust faults strike NNW-SSE and gently dip to the east, almost parallel to the beds stratification. The younger sediments on the footwall of imbricates are of intra-Oligocene age (Sotiropoulos et al., 2003). Minor back-thrusting is observed on the eastern flank of Arakynthos mountain. The eastern thrust fault zone is an elongated one, running for at least $15 \mathrm{~km}$ north of the Evinos river and separating two distinct areas. The eastern one which is mountainous including a series of rises such as Makryvouni, Kokkaliara, Froxilia composed mainly of coarse facies of flysch. It represents the hangingwall block where there are several NW-SE striking thrust faults gently dipping to the east. The thrust activity induced the intense deformation of the hanging wall strata and the widespread thrust fault related folding (Sotiropoulos 2005, Figure 4). The western one, which is an area of low relief, is dominated by fine-grained turbitides representing the footwall block. An east-verging asymmetric syncline occurs, with a long forelimb gently dipping to the east and a short steep backlimb; the strata locally are overturned especially close to the thrust front (Figure 4). The overall structural pattern suggests that the above thrust fault zone reflects the prolongation of the GT to the north (Sotiropoulos et al. 2003, Sotiropoulos, 2005).

It is worth mentioning that the turbidites occupied the footwall of the GT are the youngest found flysch sediments in the entire study area, in particular dating from 27.2 to 23.2 MA (latest Oligocene age), predating the age of the GT emplacement (Sotiropoulos et al., 2003, 2008). Furthermore, the Pindos thrust emplacement has been dated to be of Late Oligocene age (Fleury, 1980, Sotiropoulos et al., 2003, 2008). Taking into consideration all of the above, it is suggested that Pindos and GT acted simultaneously during the Oligocene (Sotiropoulos et al., 2003; 2008).

\subsection{NW Peloponnese}

Skolis mountain is the most prominent topographic feature in northwest Peloponnese representing an elongated $(9 \mathrm{~km}$ long) and narrow (1.5 km wide) structure (Figure 5). It reaches $1000 \mathrm{~m}$. of altitude superimposed on a flysch low topographic relief. The GT is situated on the western flanks of Skolis mountain, trending N-S, parallel to the mountain axis (Fleury, 1980; Kamberis et al, 2000).

In this position, Cretaceous limestones thrust over Oligocene flysch (Fleury, 1980). The thrust fault is steeply dipping to the east. Several minor synthetic thrust faults as well as minor backthrusts are identified on the hangingwall of GT. The flysch on the footwall is steeply dipping to the east and it is intensively deformed close to the thrust fault stated by tight to kink folding (Kamberis et al., 2000). Imbrication is mapped on the north-western slopes of Skolis mountain induced the repetition of the carbonate series (Figure 5). The above faults are considered to be splays rooting on the main thrust fault (Kamberis et al, 2000). Concerning the age of the GT emplacement in the study area, a late Oligocene age is inferred by the age determinations of the younger flysch members that outcrop west of Skolis mountain (Kamberis et al., 2000; 2005). 


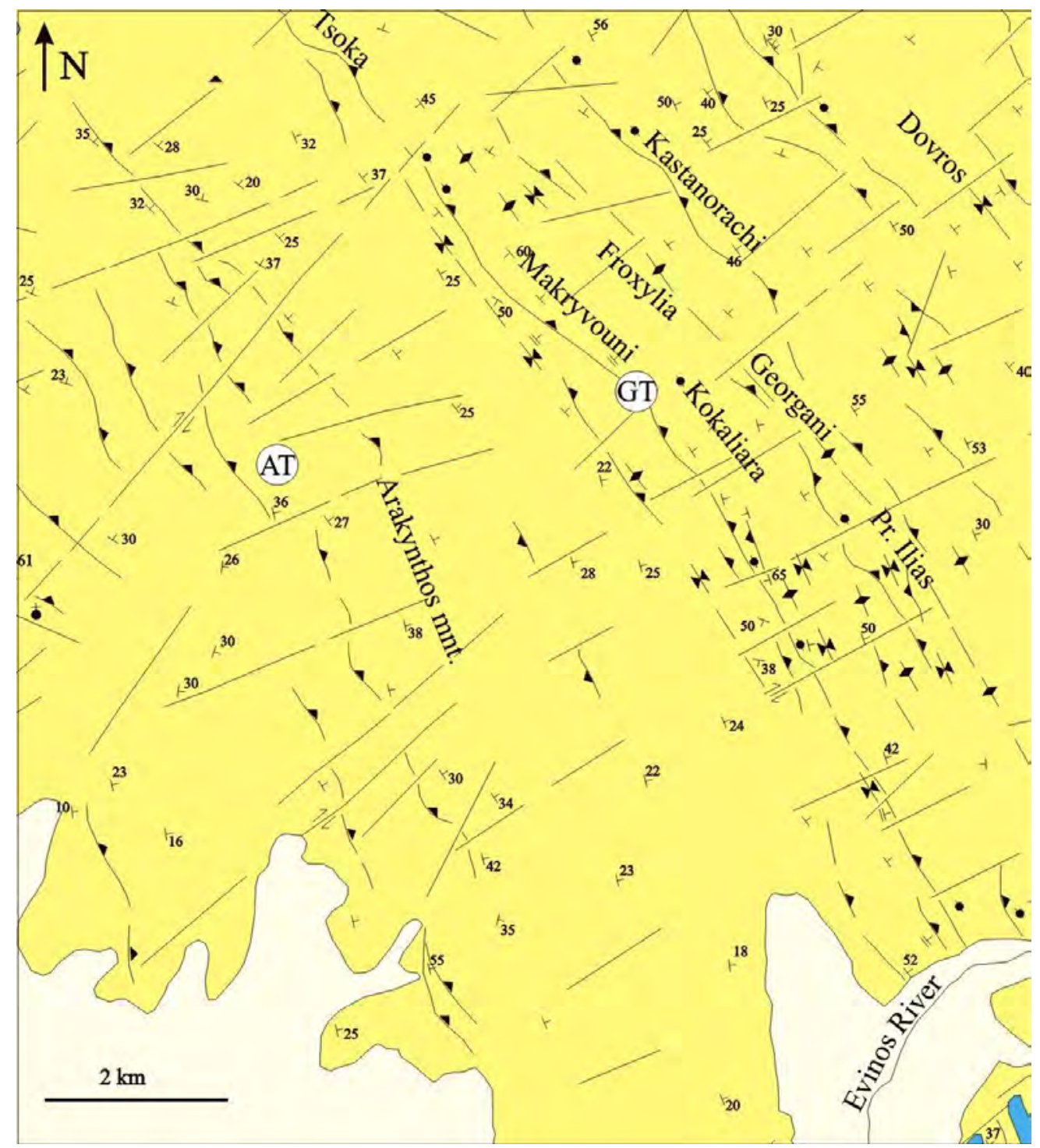

Figure 4 - Geological map of the area NW of Varassova mountain. Location B in Figure 1a. AT: Arakynthos thrust, GT: Gavrovo thrust (Sotiropoulos, 2005).

The Skolis anticline is asymmetric in shape, clearly related to the GT, (Kamberis et al., 2000). In the northern part of Skolis mountain, it represents a periclinal fold, plunging to the north, formed ahead of an advancing thrust fault. The short forelimb is dipping to the west and the long backlimb is gently dipping to the east. In the latter one, flysch overlie conformably on the Eocene carbonates. On the contrary, in the southern part of Skolis mountain, the anticline is more narrow and the carbonate strata in the backlimb are steeply dipping to the east suggesting a stronger influence of thrusting. Furthermore, on the south-eastern slopes, the carbonates are in structural contact with flysch which is gently dipping to the west (Figure 5). The contact corresponds to a major subvertical fault that in a later stage probable acted as gravitational fault, as consequence of the rotation of the hanging wall strata (Kamberis et al., 2000). It is mentioned that similar faults exist also in the eastern flank of the Varassova mountain as described before. Several E-W to WNW-ESE trending subvertical normal faults cut the earlier formed contraction structures and generally the northern ones dip to the north, while the southern ones dip to the south. 


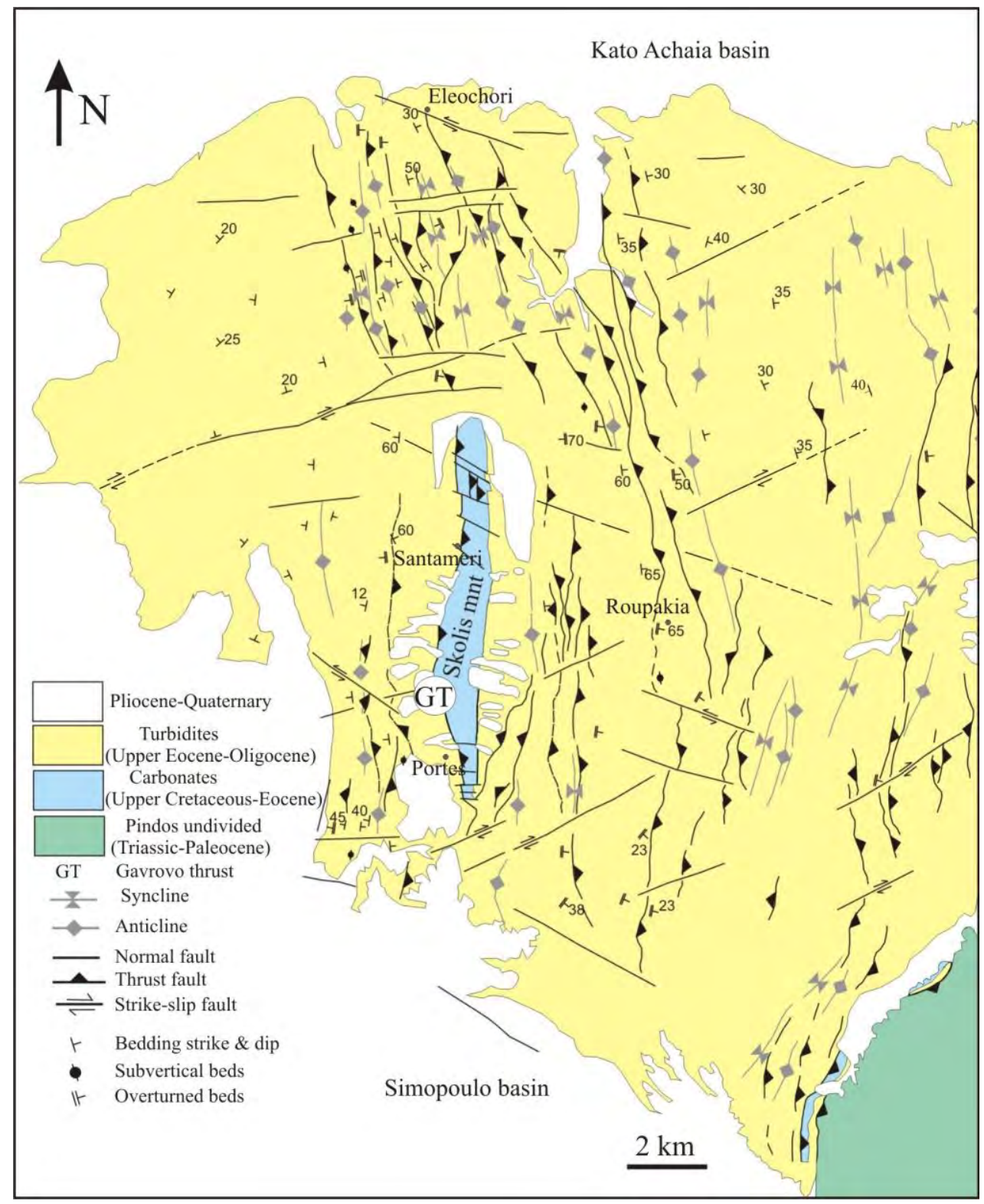

Figure 5 - Geological map of the Skolis area. Location C in Figure 1a (Kamberis et al., 2000, 2005).

An ENE-WSW trending strike-slip fault with a right-lateral sense of movement is situated north of Skolis structure, bounding the latter from a mountainous area located north of this fault (Figure 5). It consists of a series of elongated NNW-SSE to N-S trending rises with a mean altitude of $550 \mathrm{~m}$. Its structural pattern is mainly controlled by a series of close-spaced west verging thrust faults (Figure 5). Thrust fault related folds do coexist, while E-W trending normal faults cut the above structures mainly close to the southern margin of Kato Achaia basin (Figure 5). Similarly a major dextral strike-slip fault seems to cut the prolongation of the GT south of Skolis mountain (Figure 5). It is worth mentioning the existence of N-S to NNW-SSE trending west-verging thrust faults and NNE-SSW trending east-verging backthrusts southwest and southeast of Skolis mountain respectively (Figure 5). East of Skolis mountain several N-S to NNW-SSE trending and eastward 
dipping major thrust fault zones have been identified induced the significant structural thickening of Gavrovo flysch (Kamberis et al., 2000, 2005, Figure 5).

\section{Subsurface Data}

Useful subsurface information concerning the mapping of structure and the stratigraphy of the study area is derived from interpretation of seismic reflection profiles acquired for oil exploration purposes. Two seismic profiles have been selected in order to better describe of GT.

\subsection{SW Etoloakarnania area}

The first WSW-ENE trending seismic profile (Figure 6) is located north of Evinos river. The quality of the seismic reflectors is good since the overlying interval composed of thick flysch sequences. The Ionian zone lies on the western part of the seismic section, while in the uppermost eastern part appears the overriding Gavrovo zone. This contact is structural, corresponds to the major Gavrovo-Arakynthos system (GAT) that occupies the central part of the section. It is a major thrust gently dipping to the east, using the flysch of the Ionian zone as the detachment horizon. The propagation of GAT sheet to the west had as result the overloading and the down flexure of the Ionian zone as it is seen in the central part of seismic section (Sotiropoulos et al., 2003). At that point the flysch is very thick, reaching to a thickness of $2 \mathrm{sec}$ TWT below sea level.

Sub-vertical normal faults dipping to the east affect the upper part of the carbonate sequence of the Ionian zone facilitating the bending of the Ionian zone in front of the ongoing GAT. The thrust fault splays upwards into two segments (Sotiropoulos et al., 2003). The eastern segment (GT), is short and strongly curved outcropping west of Froxylia rise. The flysch appears to be intensively deformed due to imbrication in the mountainous area around Froxilia rise and this is in agreement with the field observations in this area (Figure 4). The western segment (AT), which outcrops on the western slope of Arakynthos mountain, is longer, running almost parallel to the flysch bedding.

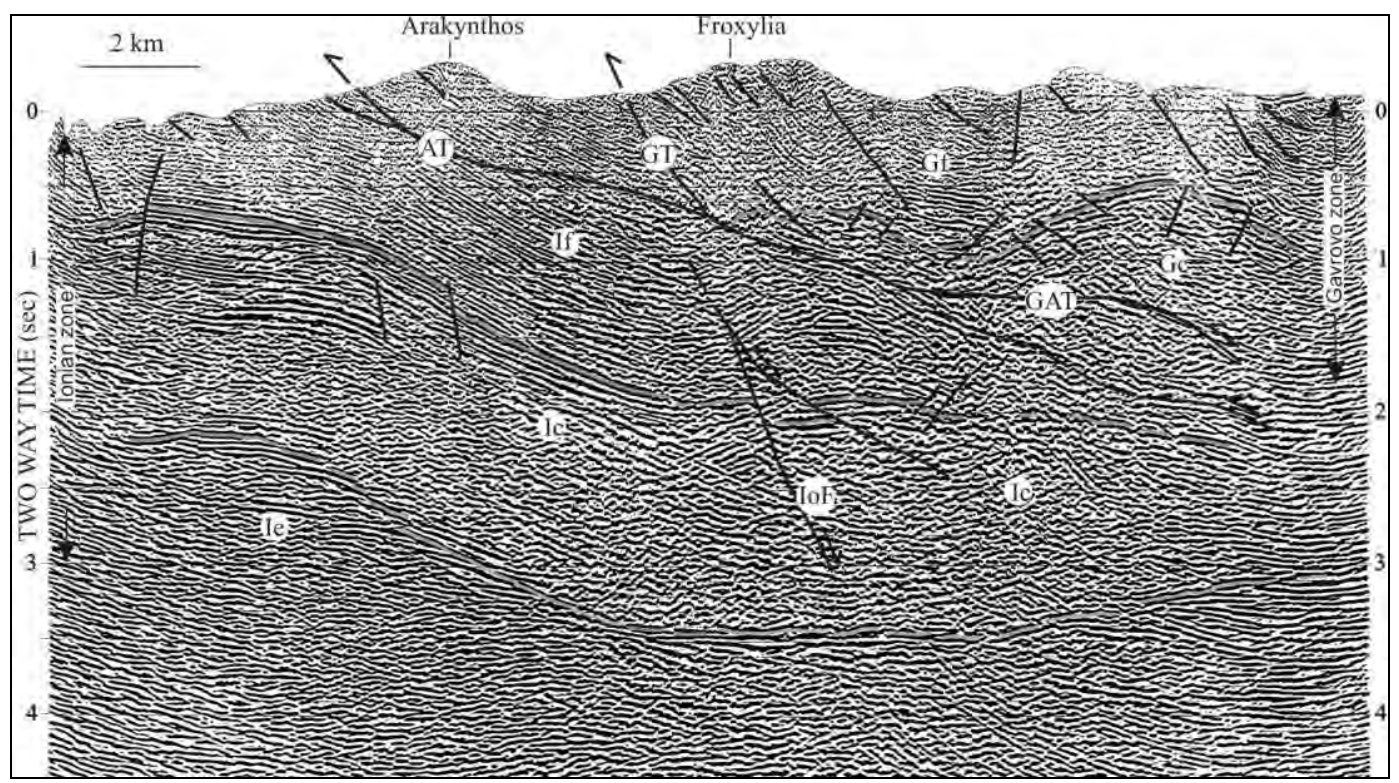

Figure 6 - Interpreted seismic reflection profile north of Evinos river (Sotiropoulos et al., 2003 partly modified). GAT: Gavrovo-Arakynthos thrust system, GT: Gavrovo splay, AT: Arakynthos splay, IoF: Ionian fault, If, Ic, Ie: flysch, carbonates and evaporites of Ionian zone, Gf, Gc: flysch and carbonates of Gavrovo zone. 
The flysch age determinations on the footwall of the above thrusts indicate that the western Arakynthos segment (AT) is the older one, while the Gavrovo segment (GT) in the rear is the younger one, suggesting that they compose an out-of-sequence thrust system (Sotiropoulos et al., 2003). Two culminations that are situated on the hangingwall of the thrust fault appear on the eastern part of seismic section corresponding to the north prolongation of Varassova and Klokova anticlines. In fact, Varassova and Klokova represent two ramp anticlines clearly associated with the ramp-flat geometry of the thrust fault surface (Sotiropoulos et al., 2003). Minor back thrusts affect the backlimb of these culminations as well as minor fore thrusts affect the western limb of Klokova anticline, supporting the field observations (Figure 4).

Two features should be pointed out in the footwall of the GT. The first one refers to the probable existence of a duplex beneath the Klokova anticline, while the second one, which is located beneath the eastern segment of GT, is a thrust related structure (Figure 6). Moreover, it is worth mentioning the existence of a subvertical normal fault (IoF in Figure 6) beneath Froxylia mountain that seems to predetermine the position of the thrust fault in its hangingwall, as well as the position of the Gavrovo thrust ramp formed in a later stage. In other words, we consider that this normal fault have played an important role in the evolution of Gavrovo-Arakynthos thrust system inducing out-of-sequence thrusting in the latest stage of its evolution.

\subsection{NW Peloponnese area}

The GT is also well documented in the second reprocessed seismic reflection profile located south of Skolis mountain (Figure 7). The strong discontinuous reflectors in the central part of the seismic profile represent the top of the carbonates of the Gavrovo zone (Gc). These carbonates are in structural contact with flysch of the Ionian zone (If) along GT. The flysch of the Ionian zone annotates the detachment horizon (Kamberis et al., 1996) as in the case of south Etoloakarnania.

Two culminations have been identified on the hangingwall of the GT. The first narrow one reflects the southern prolongation of Skolis mountain while the second one is an open buried rollover structure (Figure 7). The latter could be related with a major listric normal fault dipping to the east, representing probably the fault on the southeastern flank of Skolis mountain, as it was described earlier in this paper in the field data.

The thrust fault is characterised by a listric geometry (Kamberis et al., 2000). The upper part of the fault represents a ramp outcropping at the western flank of Skolis mountain, while the lower part gently dips to the east, following the stratification of the Ionian flysch. The displacement is estimated to exceed the $10 \mathrm{~km}$.

Based on a new interpretation of the seismic line of Figure 7, the main structural feature in the Ionian zone is a subvertical normal fault dipping to the east which is situated beneath the Skolis mountain (IoF). The extensive downthrown of the Ionian zone carbonates on the hangingwall block of this fault, suggests that it is a major normal fault. In addition, diapiric movement of the underlying Triassic evaporites may exist on the footwall block, in the vicinity to the normal fault. There are also east dipping thrust faults on the footwall of the GT west of Skolis mountain (Figure 7). They are considered to be imbricates rooting downwards on the main fault surface. Similar thrust faults are identified southwest of Skolis mountain (Figure 5). The flysch of the Gavrovo zone (Gf), in the eastern part of the seismic profile, appears to be intensively deformed by thrust faults dipping to the east. This fact is in agreement with the field data and confirms the significant structural thickening of the Gavrovo flysch (Figure 5). The decollement in the flysch sequence of the Gavrovo zone is present at the eastern part of the seismic profile. In addition, the minor folding in the Gavrovo flysch is clearly associated with the thrust activity (Figure 7). 


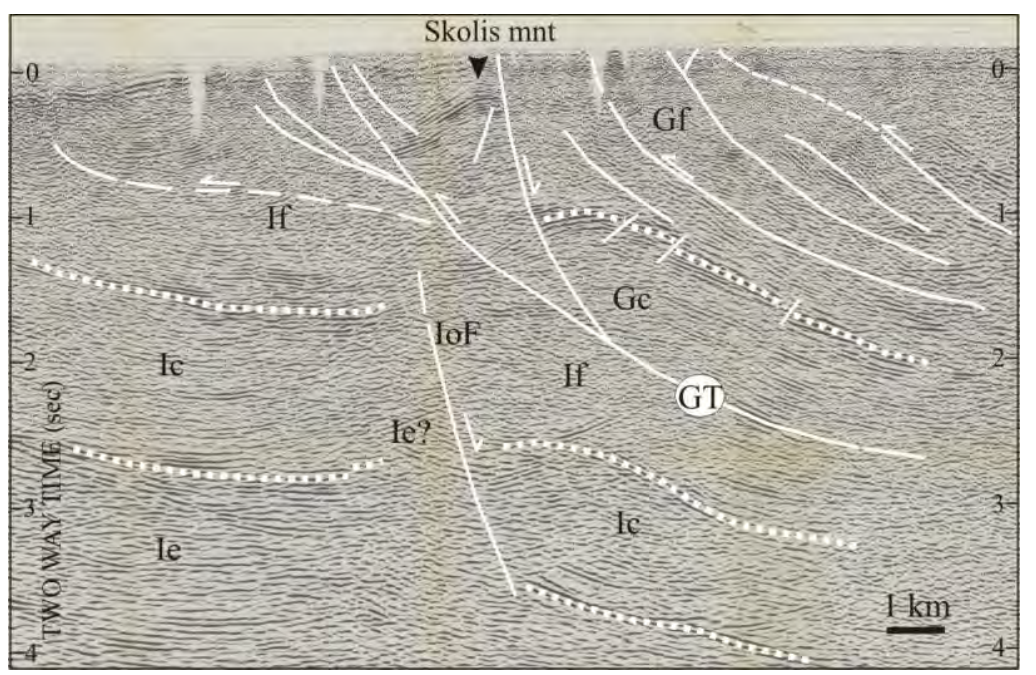

Figure 7 - Interpreted seismic reflection profile south of Skolis mountain with the same legend of Figure 6.

\section{Discussion-conclusion}

New field data and reinterpretation of subsurface data from northwest Peloponnese and the south Etoloakarnania support that, during Oligocene, the Gavrovo thrust acted simultaneously with the Pindos thrust. The flysch of the Ionian zone acted as the detachment horizon. The GT is well documented both on field and on seismic reflection profiles. It is characterised by a ramp-flat geometry and by significant displacement, greater than $10 \mathrm{~km}$ in both areas. The Klokova, Varassova and Skolis structures represent hanging wall anticlines related with the geometry of the GT. The steep relief of Skolis and Varassova mountains can be exlained by their positioning right above the frontal ramp of GT. The propagation of the GT westwards induced the flexural bending of the Ionian zone due to the thrust sheet overloading. In both regions, pre-existing sub-vertical normal faults in the Ionian zone seem to predetermine the position of the frontal ramp of the GT. In other words, there is a 'foreland influence' (term by Couples \& Lewis, 1988) in the development of this major thrust (Figure 8a). The blind normal fault beneath the Skolis mountain seems to have played an important role in the structural evolution of this area. In addition, salt movement could potentially exist along this fault. The emplacement of GT could also triggered diapirism due to the overloading of the Ionian zone.

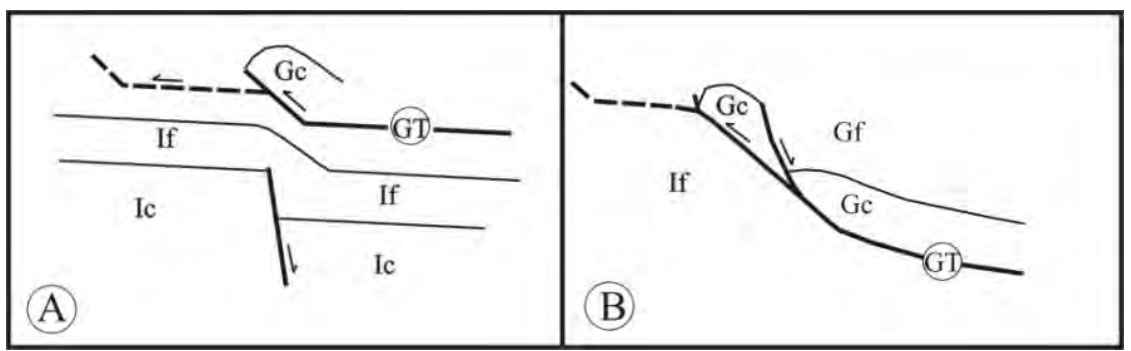

Figure 8 - Modified sketches from Couples \& Lewis, 1988. (A) Influence of the foreland structure in the geometry of GT and (B) interpretation of southern part of Skolis mountain.

Such earlier formed normal faults could act in a later stage as strike-slip faults. Koukouvelas et al., 2010 consider that the strong earthquake west of Skolis mountain in summer of 2008 correlates with this major fault in front of Skolis mountain. Sub-vertical normal faults exist at the southeastern flank of both Varassova and Skolis mountains. In the latter, the normal fault could be 
important resulting to the significant downthrown of carbonates to the east, explaining a lot the seismic image (Figure 8a). In south Etoloakarnania, the GT splays upwards in two segments. The western one is longer since it is running almost parallel to the bedding of flysch, while the eastern one is shorter and it involves out-of-sequence thrusting. In both areas the northern prolongation of the GT delineates the western boundary of a mountainous area where intensive thrusting controls its internal configuration.

\section{References}

Aubouin J. 1959. Contribution a l'etude geologique de la Grece septentrionale:les confins de l'Epire et de la Thessalie, Ann. Geol. Pays Hellen. 10, 483 pp.

BP co (British Petroleum Company Limited) 1971. The geological results of petroleum exploration in western Greece, Institute of Geology Subsurface Researsh, Athens, 10, 73 pp.

Brooks M., Clews J., Mehs N. S. and Underhill J. R. 1988. Structural development of Neogene basins in western Greece, Basin Research, 3, 129-38.

Clews J. E. 1989. Structural controls on basin evolution: Neogene to Quaternary of the Ionian zone, Western Greece, Journal of the Geological Society, London, 146, 447-57.

Couples G. and Lewis H. 1988. 'Thrust belt' structures with 'foreland' influence; The interaction of tectonic styles, Geol. Soc. Amer., Memoir 171.

Dewey J. P., Pitman W. C., Ryan,W. B. F. and Bonnin J. 1973. Plate tectonics and the evolution of the alpine system, Geological Society of American Bulletin, 84, 3137-80.

Doutsos T. and Kokkalas S. 2001. Stress and deformation in the Aegean region, Journal of Structural Geology, 23, 455-472.

Fleury J. J. 1980. Evolution d'une platforme et d'un basin dans leur cadre alpin : les zones de Gavrovo-Tripolitze et du Pinde-Olonos, Soc. Géol. du Nord, Special Publication 4, 651.

IFP (Institut Francais du Petrole) 1966. Etude geologique de l' Epire (Grece nord - occidentale), Editions Technip, Paris, France, 306 pp.

Kamberis E., Marnelis F., Loukoyannakis M., Maltezou F., Hirn A. and Streamers Group 1996. Structure and deformation of the external Hellenides based on seismic data from offshore western Greece. In: Wessely G. \& Liebl W. (Eds.): Oil and gas in Alpidic thrust belts and basins of Central and Eastern Europe, Eur. Ass. Geo. Eng., Spec. Publ., 5, Geological Society of London, 207-214.

Kamberis E., Sotiropoulos S., Aximniotou O., Tsaila-Monopoli S. and Ioakim C. 2000. Late Cenozoic deformation of Gavrovo and Ionian zone in NW Peloponnesus (western Greece), Annali di Geofisica, 43, 905-19.

Kamberis E., Pavlopoulos A., Tsaila-Monopoli S., Sotiropoulos S. and Ioakim C. 2005. Deepwater sedimentation and paleogeography of foreland basins in the NW Peloponnese (Greece), Geologica Carpathica, 56, 503-515.

Koukouvelas I., Kokkalas S. and Xypolias P. 2010. Surface deformation during the Mw 6.4 (8 June 2008) Movri earthquake in the Peloponnese and its implications for the seismotectonics of western Greece, International Geology Review, 52, 249-268.

Rigakis N. 1999. Contribution to stratigraphic research on wells and outcrops of the Alpine formations in Western Greece, in relation to the petroleum generation efficiency of their organic matter, Ph.D. Thesis, Athens University, $255 \mathrm{pp}$.

Sotiropoulos S. 2005. Stratigraphic and structural study in South Etoloakarnania, PhD. Thesis, University of Patras (in Greek).

Sotiropoulos S., Kamberis E., Triantaphyllou M. and Doutsos T. 2003. Thrust sequences in the central part of the External Hellenides, Geol. Mag., 140 (6), 661-668.

Sotiropoulos S., Triantaphyllou M., Kamberis E. and Tsaila-Monopolis S. 2008. Paleogene terrigenous (flysch) sequences in Etoloakarnania region (W. Greece), Plankton Stratigraphy and paleoenvironmental implications, Geobios, 41, 415-433.

Underhill J. 1989. Late Cenozoic deformation of the Hellenide foreland, Western Greece, Geological Society of American Bulletin, 101, 613-34.

XLVII. No 2 - 550 